KOŚCIÓŁ I PRAWO 9(22) 2020, nr 1, s. 193-206

DOI: https://doi.org/10.18290/kip2091-12

\author{
Judyta Dworas-Kulik \\ Khrystyna Moriak-Protopopowa
}

\title{
PROJEKT LUTOSTAŃSKIEGO A BOLSZEWICKIE REGULACJE PRAWNE DOTYCZĄCE PRAWA MAEŻEŃSKIEGO OKRESU MIĘDZYWOJENNEGO
}

Polska po odzyskaniu niepodległości w 1918 r. w celu zachowania ciągłości prawa nadal pozostawała pod rządami ustawodawstwa państw zaborczych. System prawa małżeńskiego tworzyło pięć obszarów prawnych. Były nimi obszary: byłego zaboru pruskiego ( $\$ 1303-1362$, $§ 1564-1588$ kodeksu cywilnego niemieckiego ${ }^{1} ; \S 67-76, \S 82-85$ ustawy o rejestracji stanu cywilnego i zawieraniu małżeństw z dnia 6 lutego $1875 \mathrm{r.}^{2}$ ), zaboru austriackiego (§ 44-136 prawa małżeńskiego austriackiego ${ }^{3}$ ) i zaboru rosyjskiego (na ziemiach wschodnich: przepisy zawarte w rosyjskim zbiorze praw, zwłaszcza

DR Judyta Dworas-KuliK - Katedra Historii Ustroju i Prawa, Instytut Nauk Prawnych, Wydział Prawa, Prawa Kanonicznego i Administracji, Katolicki Uniwersytet Lubelski Jana Pawła II; adres do korespondencji: Al. Racławickie 14, 20-950 Lublin, Polska; e-mail: dworaskulik@gmail.com; https://orcid.org/0000-0002-1990-5497

Dr Khrystyna Moriak-Protopopowa - Katedra Historii Państwa, Prawa i Nauk Prawa Politycznego, Wydział Prawa, Lwowski Uniwersytet Narodowy im. Iwana Franki; adres do korespondencji: Uniwersytecka 1, 79000 Lwów, Ukraina; e-mail: khrystyna. moryak-protopopova@Inu.edu.ua; https://orcid.org/0000-0003-1418-240X

${ }^{1}$ Kodeks cywilny obowiazujacy na ziemiach zachodnich Rzeczypospolitej Polskiej, oprac. Z. Lisowski, t. X, Wojewódzki Instytut Wydawniczy, Poznań 1933.

2 „Dziennik Ustaw Rzeszy Niemieckiej” z 1875 r., s. 23.

${ }^{3}$ Kodeks cywilny zawierajacy obowiąująca $w$ okręgach sqdów apelacyjnych $w$ Krakowie $i$ Lwowie oraz sqdu okręgowego $w$ Cieszynie ustawe cywilnq, ustawy $i$ rozporzadzenia dodatkowe, z uwzględnieniem ustawodawstwa polskiego, oraz orzecznictwa Sqdu Najwyższego, oprac. W. Dbałowski, J. Przeworski, Księgarnia F. Hoesicka, Warszawa 1927. 
w t. X, cz. 1 Zwodu Praw Cesarstwa Rosyjskiego z 1832 r. ; art. 1-108 oraz częściowo t. XI, cz. 1, zaś na obszarze ziem centralnych: prawo o małżeństwie z dnia 24 czerwca 1836 r. $^{5}$ ) oraz dwadzieścia siedem wiosek Spiszu i Orawy, przyłączonych do Rzeczypospolitej w 1922 r. [Mezglewski i Tunia 2007, 1-2; Stawecka-Firlej 2013, 75; Dworas-Kulik 2017, 109-10; Taż, 2019, 19-49], gdzie w chwili przyłączenia obowiązywało węgierskie prawo małżeńskie z 1894 r. [Allerhand 1926, 1-39]. Próbą eliminacji mozaiki prawnej była uchwalona przez sejm ustawodawczy ustawa o Komisji Kodyfikacyjnej z dnia 3 czerwca 1919 r., której celem było m.in. ujednolicenie prawa małżeńskiego na terytorium Rzeczypospolitej. Dnia 2 czerwca 1924 r. stanowisko referenta objął K. Lutostański, dlatego też nowy projekt prawa małżeńskiego nazywany był jego nazwiskiem. Projekt został uchwalony przez Komisję Kodyfikacyjną dnia 4 października 1927 r. Należy zauważyć, iż przez długi czas wstrzymywano go na szczeblu Podkomisji z uwagi na opinię społeczną, zwłaszcza środowisk konserwatywnych. Polscy biskupi katoliccy zwrócili się do przedstawicieli rządu i stronnictw poselskich (katolików) o zabezpieczenie katolickim związkom małżeńskim ich charakteru sakramentalnego powołując się na świętość życia rodzinnego oraz trwałość i pomyślność życia narodowego i państwowego. Podkreślali, iż związek małżeński zawarty przed urzędnikiem stanu cywilnego był nieważny, gdyż sprzeciwiał się prawu Bożemu ${ }^{6}$ [Bilczewski 1924, 320-43; Rulikowski 1932, 161-70; Godlewski 1967, 756-59; X. 1932, 376; Wyszyński 1928, 20, 32]. Również w Orędziu Episkopatu Polski w sprawie projektu ustawy o małżeństwie biskupi katoliccy powołując się na encyklikę o małżeństwie chrześcijańskim papieża Piusa XI z dnia 31 grudnia 1930 r. $^{7}$ oraz art. 114 Konstytucji marcowej ${ }^{8}$ domagali się zabezpieczenia charakteru sakralnego katolickich związków małżeńskich. Jednocześnie zarzucali

${ }^{4}$ Prawo cywilne Ziem Wschodnich, $t$. X Cz. I Zwodu praw rosyjskich, tekst podtug wydania urzędowego z roku 1914 z uwzględnieniem zmian wprowadzonych przez ustawodawce polskiego oraz ustawy zwiqzkowe, tudzież judykatura Sadu Najwyższego $i$ b. Senatu t. I, oprac. Z. Rymowicz, W. Święcicki, Księgarnia F. Hoesicka, Warszawa 1933.

5 „Dziennik Praw Królestwa Polskiego” z 1836 r., t. XVIII, Nr 64, s. 57-297.

${ }^{6}$ Odezwa Biskupów Polski do Rzqdu i Narodu w obronie Sakramentu Matżeństwa, „Wiadomości Diecezjalne Podlaskie” 3 (1926), s. 81-82.

${ }^{7}$ Pius PP. X, Litterae encyclicae de Matrimonio christiano spectatis praesentibus familiae et societatis condicionibus, necessitatibus, erroribus, vitiis Casti connubii (31.12.1930), AAS 22 (1930), s. 539-92; tekst polski w: „Wiadomości Archidiecezjalne Warszawskie" 21 (1931), s. 57-95.

${ }^{8}$ Ustawa z dnia 17 marca 1921 r., Dz. U. Nr 44, poz. 267. 
podeptanie zasady nierozerwalności małżeństwa i wprowadzenie związków czasowych, co w opinii Episkopatu zbliżało Polskę do bolszewickiej Rosji ${ }^{9}$ [Szczepaniak 2015, 96-104; Woźniczek 2011, 132-41; Biskupski 1930, 13-39; Tenże 1932]. Ostatecznie dnia 28 maja 1929 r. Komitet Organizacji Prac uchwalił projekt w skróconym trybie, który następnie w dniu 4 grudnia 1929 r. został przesłany Ministrowi Sprawiedliwości, lecz z jego opublikowaniem Komisja Kodyfikacyjna nadal się wstrzymywała. Dnia 9 grudnia 1931 r. wydrukowano uzasadnienie projektu prawa małżeńskiego, jednakże samego projektu nie uchwalono. Środowiska konserwatywne zwalczały projekt Lutostańskiego w środkach masowego przekazu [Lutostański 1932a, 289-92; Tenże 1932b, 525-30, 557-62; Dbałowski 1932, 71-72; Bekerman 1932, 58993, 605-606], dlatego też rząd zrezygnował z projektu jako podstawy prawa małżeńskiego obowiązującego w Rzeczypospolitej. Komisja Kodyfikacyjna uznała swoje prace w tej materii za zakończone i ostateczne ${ }^{10}$ [Dworas-Kulik 2019, 199-202; Fiedorczyk 2005, 89-96].

Uwzględniając zasygnalizowane przyczyny i argumenty, które zaważyły na tym, że projekt Lutostańskiego nie miał mocy obowiązującej, celem artykułu jest historyczno-prawna analiza tego projektu. Zostanie ona przeprowadzona również w ujęciu prawno-porównawczym, w jego aspekcie wertykalnym [Pawluk 2002, 37] pozwalającym na ustalenie ewentualnego wpływu i przenikania się $\mathrm{w}$ projekcie regulacji bolszewickich $\mathrm{w}$ zakresie prawa małżeńskiego. Przedstawiciele hierarchii kościelnej w Polsce dostrzegali w projektowanym prawie niektóre rozwiązania zbliżone ideologicznie do bolszewizmu, w związku z tym komparatywnym obszarem prawnym dla projektu Lutostańskiego w niniejszym artykule staną się dekrety Wszechrosyjskiego Centralnego Komitetu Wykonawczego i Rady Komisarzy Ludowych Rosyjskiej Federacyjnej Socjalistycznej Republiki Radzieckiej.

${ }^{9}$ W sprawie projektu ustawy o matżeństwie. Orędzie Episkopatu Polski, „Miesięcznik Kościelny dla Archidyecezyi Gnieźnieńskiej i Poznańskiej” 11 (1931), s. 206-207.

${ }^{10}$ Komisja Kodyfikacyjna. Podsekcja I Prawa cywilnego, Zasady projektu prawa matżensskiego $w$ opracowaniu referenta głównego prof. K. Lutostańskiego, uchwalone $w$ dniu 28 maja 1929 r., t. I, z. 3, Komisja Kodyfikacyjna, Warszawa 1931, s. 3-17. 


\section{ZAWARCIE MAŁŻEŃSTWA W PROJEKCIE LUTOSTAŃSKIEGO}

Projekt Lutostańskiego ${ }^{11}$ opierał się na zasadzie jednolitości prawa oraz równości wszystkich obywateli, bez względu na wyznanie czy płeć. Według projektu małżonkowie wspólnie sprawowali zarząd nad gospodarstwem domowym oraz wzajemnie dostarczali sobie i dzieciom utrzymania. O miejscu zamieszkania małżonków decydowało miejsce zamieszkania męża, jednak $\mathrm{w}$ art. 33 projektu zawarty był wyjątek od tej reguły, bowiem w razie sporu ostateczną decyzję podejmował małżonek, który ponosił główny koszt utrzymania rodziny.

Prawnym wymogiem zaręczyn było posiadanie przez strony zdolności do wstąpienia w związek małżeński. Oświadczenie woli zawarcia związku małżeńskiego, zarówno przed urzędnikiem stanu cywilnego, jak i przed duchownym, należało złożyć publicznie, w obecności dwóch świadków (art. 24). Materialną ważność małżeństwa potwierdzało uzyskane wcześniej zaświadczenie o braku przeszkód. Małżeństwo bez tego dokumentu ulegało unieważnieniu na mocy art. 47. W projekcie wprowadzono fakultatywną formę ślubów cywilnych. Jednak dla aktu małżeństwa nie miała znaczenia forma, w jakiej oświadczenie woli zawarcia małżeństwa zostało złożone. Skuteczność prawną nadawano małżeństwom wpisanym w księgach stanu cywilnego. Przy formie cywilnej następowało to przez sporządzenie aktu małżeństwa, zaś w odniesieniu do formy religijnej - wskutek sporządzonego przez duchownego bezpośrednio po zawarciu małżeństwa protokołu, który po podpisaniu przez małżonków i świadków był przekazywany do urzędu stanu cywilnego. Protokół bez odpowiedniego wpisu w księgach stanu cywilnego nie stanowił dowodu zawarcia małżeństwa. W wyjątkowych okolicznościach, przez które należało rozumieć wybuch wojny, małżonka podczas aktu małżeństwa mógł zastąpić pełnomocnik (art. 27). Natomiast w obliczu śmierci jednego z nupturientów, dla zachowania ważności małżeństwa, wystarczyło publiczne oświadczenie woli zawarcia małżeństwa, wypowiedziane w obecności dwóch świadków (art. 29). W projekcie Lutostańskiego przeszkody małżeńskie dzielono na względne, niepowodujące unieważnienia małżeństwa, i bezwzględne. Zaistnienie tych ostatnich stanowiło podstawę nieważności małżeństwa. Przyczynami bezwzględnymi były: bigamia, pokrewieństwo

${ }^{11}$ Taż, Projekt prawa matżeńskiego uchwalony przez Komisję Kodyfikacyjnq $w$ dniu 28 maja 1929, t. I, z. 1, Komisja Kodyfikacyjna, Warszawa 1931. 
w linii prostej, choroba umysłowa oraz wiek 20 lat u mężczyzn i 17 lat u kobiet, chyba że rodzice wyrazili zgodę na wcześniejszy akt małżeństwa lub kobieta była w ciąży. Kwestie sporne rozstrzygał sąd. Przyczynami względnymi były: pokrewieństwo między bliskimi krewnymi, choroba weneryczna w stanie zaraźliwym lub narkomania, niedopuszczalne było również małżeństwo z osobą dotkniętą ostrą gruźlicą i pomiędzy przysposobionymi. W regulacjach projektowych nie była znana instytucja dyspensy od przeszkód małżeńskich. Według art. 19 projektu prawa małżeńskiego wykonanie czynności zmierzających do sprawdzenia przeszkód małżeńskich powierzono urzędnikowi stanu cywilnego właściwego dla miejsca zamieszkania jednego $\mathrm{z}$ nupturientów lub dla miejsca jego pobytu, jeśli przebywał on $\mathrm{w}$ danym miejscu przez okres nie krótszy niż 4 tygodnie. Dodatkowo zobowiązywano rodziców lub opiekunów, a w przypadku ich braku dwóch wstępnych bądź rodzeństwo każdego z narzeczonych, do złożenia oświadczenia o nieposiadaniu wiedzy co do istnienia przeszkód małżeńskich. Uzyskane od urzędnika stanu cywilnego zaświadczenie o nieistnieniu przyczyn uniemożliwiających zawarcie małżeństwa uprawniało do wstąpienia w związek małżeński według formy wybranej przez nupturientów.

\section{ZAWARCIE MAŁŻEŃSTWA WEDŁUG USTAWODAWSTWA BOLSZEWICKIEGO}

W przypadku regulacji bolszewickich okresu międzywojennego pierwszymi aktami normatywnymi regulującymi podstawy prawa małżeńskiego były dekrety Wszechrosyjskiego Centralnego Komitetu Wykonawczego i Rady Komisarzy Ludowych Rosyjskiej Federacyjnej Socjalistycznej Republiki Radzieckiej z 18 grudnia 1917 r. O zwiqzku matżeńskim cywilnym, o dzieciach i o prowadzeniu ksiag aktów stanu i z 19 grudnia 1917 r. O rozwiazaniu małżeństwa. W dekrecie z 18 grudnia 1917 r. przewidywano tylko śluby cywilne. Ślub zawarty w Kościele uważano za prywatną sprawę małżonków. Nie wywoływał skutków prawnych w prawie cywilnym, stąd nie podlegał obowiązkowej rejestracji cywilnej (dekret z 18 grudnia 1917, wstęp) [Safonchyk 2011, 281]. Dopiero od 1926 r. śluby zawarte w formie wyznaniowej i niezarejestrowane wywoływały skutki prawne [Giduljanov 1927, 10].

Przesłankami zawarcia małżeństwa w uregulowaniach bolszewickich było osobiste stawiennictwo przed osobą udzielającą ślubu i złożenie zgod- 
nych oświadczeń woli w formie pisemnej (dekret z 18 grudnia 1917, art. 1 i 3). Do przeszkód małżeńskich należały: wiek poniżej 18 lat u mężczyzn i 16 lat u kobiet [Yasynok 2008, 90], pokrewieństwo pomiędzy krewnymi w linii prostej oraz pomiędzy dziećmi małżeńskimi i pozamałżeńskimi, a w linii bocznej między rodzonymi lub przyrodnimi dziećmi. Do przeszkód małżeńskich zaliczano również bigamię, zaburzenia psychiczne lub niepełnosprawność intelektualną (art. 2). Dopuszczano śluby z bliskimi krewnymi w linii bocznej, np. stryjem i siostrzenicą oraz między przybranymi rodzicami i przybranymi dziećmi. Nie wzbraniano także małżeństwa osób tej samej płci. Nupturienci byli zobowiązani podpisać zapewnienie o braku okoliczności wyłączających zawarcie małżeństwa (art. 3). Za przedstawienie nieprawdziwej informacji była przewidziana odpowiedzialność karna, a sam ślub uznawano za nieważny. Ślub zawierano w dniu zgłoszenia się do urzędu bez wcześniejszego ustalania terminu ceremonii. Na potwierdzenie rejestracji ślubu w aktach stanu cywilnego na prośbę małżonków kierownik działu rejestracji ślubów wydawał kopię aktu małżeństwa. Lakoniczny dekret nie przewidywał możliwości zawarcia małżeństwa w formie zaocznej, czyli przy nieobecności jednej ze stron.

W 1918 r. został przyjęty pierwszy radziecki kodeks - Kodeks o aktach cywilnego stanu, ślubnym, rodzinnym i opiekuńczym prawie, na mocy którego przewidywano wyłącznie publiczną formę zawarcia małżeństwa w specjalnie przeznaczonym do tego celu pomieszczeniu i po uprzednim określeniu z urzędnikiem stanu cywilnego dokładnej daty i godziny ceremonii ${ }^{12}$ (art. 52-54). Procedura przedstawienia oświadczenia woli o wstąpieniu w związek małżeński i regulacje prawne dotyczące rejestracji małżeństwa nie uległy zmianie w stosunku do dekretów z 1917 r. Dopuszczono osoby trzecie do składania oświadczeń w zakresie istnienia przeszkód małżeńskich. Powzięcie takiej informacji przez urzędnika stanu cywilnego wstrzymywało procedurę rejestracji małżeństwa, a sprawę przekazywano do rozpatrzenia przez sąd, który powinien podjąć decyzję w zakresie możliwości zawarcia małżeństwa w ciągu 3 dni (art. 63). Na mocy Kodeksu z 1918 r. wiek małżonków nie stanowił podstawy unieważnienia zawartego przez nich związku, o ile zarzut istnienia przeszkody wieku podniesiono, gdy mężczyzna ukończył 18 lat, a kobieta 16 lub w sytuacji ciąży bądź urodzenia dziecka. W Kodeksie z 1918 r.

${ }^{12}$ Wyjątek od tej reguły przewidziano dla ciężko chorych, wojskowych oraz w przypadku ślubów na statkach morskich. 
przynależność małżeństwa do różnych wyznań nie stanowiła przeszkody małżeńskiej; podobnie jak niemoc płciowa, powinowactwo, pokrewieństwo prawne, czy święcenia (art. 71). Zarejestrowane w aktach stanu cywilnego małżeństwa były zrównane związkom nieformalnym (konkubinatom). Różnica między tymi związkami sprowadzała się jedynie do kwestii materialnej pomocy małżonkom, która była zabezpieczona prawnie ${ }^{13}$.

Należy zaznaczyć, iż w 1926 r. Ogólnorosyjski Centralny Wykonawczy Komitet ogłosił przyjęcie nowego Kodeksu $O$ ślubie, rodzinie $i$ kurateli, który co do zasady ugruntował dotychczasową praktykę w zakresie prawa małżeńskiego. Zmianie uległ jedynie wiek nupturientów. Ustalono jednakową granicę wieku 18 lat dla obojga nupturientów. Ponadto wprowadzono pojęcie faktycznych ślubnych stosunków (konkubinatu). Rozgraniczono moment ich powstania i rejestracji [Giduljanov 1927, 10]. Osoby, które przebywały w faktycznych stosunkach ślubnych miały prawo rejestracji związku w dowolnym terminie, przy czym w akcie stanu cywilnego jako datę zawarcia małżeństwa wpisywano odpowiadającą momentowi nawiązania konkubinatu [tamże, $25]^{14}$. Dowodami istnienia faktycznych związków małżeńskich były okoliczności wspólnego zamieszkiwania i prowadzenia wspólnego gospodarstwa domowego, przejawy stosunków ślubnych przed osobami trzecimi, a także w osobistej korespondencji i w innych dokumentach. Również w zależności od okoliczności brano pod uwagę wzajemne materialne wsparcie, czy też wspólną edukację dzieci [tamże, 72].

${ }^{13}$ Taki stan rzeczy zupełnie odpowiadał panującej państwowej ideologii marksizmu. W komunistycznych poglądach rodzina nie stanowiła gospodarczej jednostki, która jednoczy małżeństwo. Była miejscem emocjonalnego i seksualnego zadowolenia. Zasadę równoprawności małżeństw formalnych i nieformalnych realizowano w pełnej mierze, gdyż twierdzono, że ingerencja państwa do tych stosunków małżeńskich nie była stosowna ani konieczna [Posvistak 2015]. Dana teza znajduje swoje potwierdzenie w sądowej praktyce, bowiem sądy ludowe nieraz przyznawały prawo do majątku zmarłego osobie, która przebywała ze spadkodawcą w faktycznych stosunkach ślubnych (konkubinacie) [Prigradov-Kudrin 1922].

${ }^{14}$ Mimo, że ustawodawca przewidywał monogamię, nie karano za pozostawanie $\mathrm{w}$ faktycznych związkach z kilkoma partnerami czy jednoczesnym funkcjonowaniu w zarejestrowanym małżeństwie i konkubinacie. Sankcję karną stosowano tylko w przypadku próby zawarcia ponownego małżeństwa przed formalnym rozwiązaniem poprzedniego, choćby nieformalnego związku [Giduljanov 1927, 41]. 


\section{REGULACJE PRAWNE DOTYCZĄCE ROZWIĄZANIA MAEŻEŃSTWA}

Małżeństwo według projektu Lutostańskiego ustawało wskutek śmierci jednego z małżonków bądź na skutek zniesienia wspólnoty małżeńskiej, która stanowiła odmianę rozłączenia od stołu i łoża lub przez orzeczenie rozwodu. S. Biskupski podkreślał, iż rozwody sprzeciwiały się przyrodzonemu prawu przynosząc nieobliczalne w skutkach szkody oraz powodując zerwanie wspólnoty z Kościołem. Wskazywał także, iż rozwody należało traktować jako gwałt przeciw naturalnym prawom rodziny i jedną z przyczyn rozkładu poszczególnych społeczeństw, zaś nierozerwalność małżeństwa jako ich najlepszą ostoję [Biskupski 1932, 31-40]. W podobnym tonie wypowiedział się S. Trzeciak porównując projekt prawa małżeńskiego z bolszewickim kodeksem ustaw o małżeństwie. Wskazał, iż uznanie małżeństwa nie za sakrament, a za zwykły kontrakt - akt stanu cywilnego, który można było bardzo łatwo zerwać bez podania powodów, prowadziło do zezwierzęcenia w życiu rodzinnym i do wyniszczenia Kościoła. Podkreślał, iż kobieta przy ślubach cywilnych zostaje sprowadzona do roli zabawki, której mężczyzna w każdej chwili mógł się pozbyć dla młodszej wybranki [Trzeciak 1932, 32-33, 49]. W projekcie Lutostańskiego przewidywano jurysdykcję cywilną sądów powszechnych. Sądy cywilne miały orzekać o skutkach zawartego małżeństwa, nie stwierdzały natomiast nieważności małżeństwa religijnego (art. 24). Przy orzekaniu o rozwiązaniu związku małżeńskiego sąd oceniał, czy małżonek posiadał zaświadczenie o nieistnieniu przeszkód, o ile powództwo nie dotyczyło ślubu kościelnego. Ze względu na interes publiczny przewidywano udział prokuratora w sprawach o unieważnienie małżeństwa i o zmianę separacji na rozwód. W projekcie prawa małżeńskiego nakazywano doręczanie prokuratorowi powództwa o stwierdzenie nieważności małżeństwa oraz wezwań na posiedzenia sądowe. Prawomocny wyrok sądu cywilnego obowiązywał obie strony oraz zachowywał moc prawną wobec osób trzecich. Prokurator mógł przed sądem przedstawiać dowody, stawiać wnioski, zaś wyrok był wydawany po ich wysłuchaniu. Poparcie przez prokuratora skargi o nieważność wiązało się z prowadzeniem sprawy pomimo dalszej nieobecności stron procesowych. Strony nie mogły ubiegać się o zwrot kosztów za jego obecność w procesie. Podstawą żądania unieważnienia małżeństwa były: wady oświadczenia woli występujące przy zawieraniu małżeństwa, błąd co do osoby, przymus i obawa. Unieważnienie małżeństwa wywoływało 
takie same skutki, jak rozwód, lecz było traktowane jako surowszy środek zabezpieczenia interesu publicznego (art. 47-53).

Przyczynami rozwodu w rozumieniu projektu Lutostańskiego były: cudzołóstwo, nastawanie na życie współmałżonka, ciężkie obelgi i potwarze, o ile od wystąpienia tych okoliczności nie minęły 3 lata lub 6 miesięcy od dowiedzenia się o nich przez powoda. Inną przyczyną był błąd lub przymus, w przypadku których skarga przedawniała się w ciągu 6 miesięcy od poznania przez małżonka tego błędu lub ustania przymusu. W przypadku niedotrzymania przyrzeczenia zawarcia małżeństwa wyznaniowego skarga gasła po trzech miesiącach od zawarcia aktu małżeństwa. Orzeczenie o winie miało wpływ jedynie na skutki materialne związane z rozłączeniem, nie zaś na samą dopuszczalność orzeczenia rozwodu. W sprawach o rozwód dopuszczano system pośredni dowodu. Polegał na nieujawnianiu publicznie przyczyn rozwodu i rozłączenia, a rozwód zapadał w wyniku wspólnej zgody i woli małżonków co do rozwiązania małżeństwa (art. 58).

Rozwód za zgodą małżonków orzekano również w przypadku, gdy małżonkowie byli we wspólności od 3 lat, mieli ukończone 25 lat i byli bezdzietni. W projekcie Lutostańskiego możliwa była zmiana separacji na rozwód. $\mathrm{W}$ takim przypadku nie było konieczne nowe postępowanie przed sądem. Warunek zmiany orzeczenia sprowadzał się do oceny dobra małoletnich dzieci. Sąd stwierdzał, czy ze względu na wiek dzieci, ich potrzeby, stosunek do nich rodziców oraz nową sytuację prawną małżonków mógł dopuścić rozwód. W sprawie o rozwód przewidywany był udział prokuratora, który miał uprawnienie do zaskarżenia wyroku ze względu na dobro małoletnich dzieci. O zmianę wyroku na rozwodowy można było wystąpić po upływie 3 lat od rozłączenia od stołu i łoża. Okres ten ulegał skróceniu, jeśli uzasadniały to szczególne przypadki dokładnie zbadane przez sąd, np. nieuleczalna choroba umysłowa współmałżonka, niemoc płciowa, nieuleczalna choroba zaraźliwa, a także skazanie na długotrwałe pozbawienie wolności. Upływ 7 lat od chwili zawarcia małżeństwa i 4 lat od wystąpienia do sądu o rozłączenie traktowano jako okres niezbędny do uzyskania rozwodu, bowiem tylko określony upływ czasu dawał dostateczną gwarancję, że ta forma nie stanie się środkiem obejścia prawa. Prawomocny wyrok sądu uprawniał do zawarcia ponownego związku małżeńskiego (art. 79). Rozwiedziona małżonka postanowieniem sądu zachowywała nazwisko męża, o ile miała małoletnie dzieci.

W regulacjach bolszewickich małżeństwo ustawało wskutek śmierci jednego z małżonków lub uznania za zmarłego. W dekrecie $O$ rozwiazaniu 
małżeństwa z 19 grudnia 1917 r., a następnie Kodeksach z 1918 r. i z 1926 r. dopuszczano rozwód bez podania przyczyn rozkładu małżeństwa. Decyzja o rozwodzie niczym nie była ograniczona. Zatem brano pod uwage jedynie wolę stron co do rozwiązania małżeństwa [Kushnir 2010, 178-79]. Jedyną różnicę stanowiła od 1918 r. możliwość zaskarżenia wyroku i jego kasacji.

\section{SYTUACJA PRAWNA ŻONY I DZIECI W ZWIĄZKU Z ROZWIĄZANIEM MAŁŻEŃSTWA}

W projekcie Lutostańskiego wraz z rozłączeniem małżeństwa ustawało domniemanie ojcostwa względem dziecka poczętego przez żonę rozłączoną. Przy zerwaniu wspólnoty rodzinnej dziecko powierzano małżonkowi niewinnemu, a wraz z nim zarząd i użytkowanie jego majątku. W sytuacji, gdy dziecko powierzono osobie trzeciej, żadne z rodziców nie miało prawa do zarządu i użytkowania majątku swego potomka. Sąd określał również udziały każdego z rodziców w ciężarach utrzymania oraz wychowania dziecka. Zapewniał rodzicowi niepozbawionemu władzy rodzicielskiej możliwość wykonywania dozoru nad wychowaniem i wykształceniem dziecka oraz prawo utrzymania z nim osobistych stosunków w warunkach z góry określonych przez sąd. Jeśli rodzic był pozbawiony władzy rodzicielskiej, nie mógł mieć innych praw, jak tylko widzenie się z dzieckiem, o ile sąd uznał to za dopuszczalne ze względu na interes dziecka (art. 72). W myśl postanowień art. 64 ustawało prawo spadkobrania oraz korzyści wynikające dla małżonków z majątkowej umowy małżeńskiej, lub też z rozporządzenia na wypadek śmierci, które sporządzono przed orzeczeniem sądu w przedmiocie rozłączenia. Winny małżonek odpowiadał za szkody wynikłe $\mathrm{z}$ rozwodu, z tytułu utraty korzyści płynących z istniejącego związku małżeńskiego oraz z majątkowej umowy małżeńskiej i krzywdy moralnej doznanej na skutek rozłączenia. Ponadto dostarczał środków utrzymania niewinnemu małżonkowi (art. 67). Winny rozpadu pożycia małżeńskiego mógł żądać środków na utrzymanie, jeśli sąd orzekł obustronną winę małżonków. Środki na utrzymanie były świadczeniem pomocniczym, zatem odpowiadały sytuacji materialnej i potrzebom obojga stron.

W dekrecie $O$ rozwiazaniu matżeństwa z 19 grudnia 1917 r. wskazywano, iż sąd orzekając o rozwodzie rozstrzygał kwestie dotyczące sprawowania bezpośredniej opieki nad małoletnimi dziećmi, nazwiska które będą nosiły 
oraz czy ojciec powinien materialnie wspierać dzieci i byłą żonę (art. 1-12). W ustawodawstwie bolszewickim na rozwiedzionej kobiecie spoczywała odpowiedzialność za edukację i materialne utrzymanie potomstwa. Państwo nie dbało o zachowanie ciągłości rodziny, a ponadto nie przyznawało materialnej opieki samotnej matce z małoletnimi dziećmi, co stawiało rozwiedzioną kobietę w trudnej sytuacji, ponieważ zazwyczaj w czasie trwania małżeństwa żona nie pracowała, a jedynie prowadziła gospodarstwo domowe i zajmowała się edukacją dzieci [Mikheieva 2013, 130].

\section{PODSUMOWANIE}

Celem twórców polskiego prawa małżeńskiego było utrzymanie ciągłości rodziny jako podstawowej komórki społecznej, która buduje społeczeństwo i państwo, stąd wprowadzono w projekcie przesłanki rozwodowe. Uznawano, iż odmowa udzielenia rozwodu czyniła taki przepis martwym, nieszanowanym i obchodzonym przez społeczeństwo, co skutkowało brakiem sprawowania przez prawo swej funkcji regulacyjnej i kontrolnej. Ponadto wprost prowadziło do konkubinatu, przez co odmawiało ochrony prawnej faktycznej partnerce, zaś dzieci z takiego związku czyniło nieślubnymi. Intencją zaś bolszewickiego ustawodawcy było zburzenie tradycyjnego postrzegania instytucji małżeństwa i rodziny celem ugruntowania w społeczeństwie socjalistycznego modelu rodziny i państwa. Negatywne skutki absolutnej wolności rozwodów już w najbliższym dziesięcioleciu doprowadziły do zmniejszenia urodzeń, zwiększenia liczby bezdomnych i porzuconych dzieci oraz dokonanych przez nich przestępstw. Rozwiedzione matki były zmuszone pracować, ażeby wyżywić rodzinę, a ich dzieci zostawały bez należytej opieki i edukacji. Należy zatem wskazać, iż projekt Lutostańskiego nie miał charakteru typowo świeckiego. Wprowadzono w nim elementy charakterystyczne dla typu wyznaniowego małżeństwa. Nie można go było porównać do bolszewickiego ustawodawstwa $\mathrm{z}$ okresu międzywojennego, gdyż regulacje prawne obu ustawodawstw tylko w nielicznych przypadkach pokrywały się w swej treści. 


\section{PIŚMIENNICTWO}

Allerhand, Maurycy. 1926. „Prawo małżeńskie obowiązujące na Spiszu i Orawie, odbitka z czasopisma." Przeglad Prawa i Administracji 10-12:1-39.

Bekerman, Józef. 1932. „Z powodu Projektu prawa małżeńskiego.” Gazeta Sądowa Warszawska 60, nr 41:589-93, nr 42:605-606.

Bilczewski, Józef. 1924. Listy pasterskie, odezwy, kazania i mowy okolicznościowe. T. 3. Lwów: Bibljoteka Religijna.

Biskupski, Stefan. 1930. „Reforma prawa małżeńskiego w Polsce.” [odbitka z Ateneum Kapłańskiego 25].

Biskupski, Stefan. 1932. O nowe prawo małżeńskie $w$ Polsce. Włocławek: Diecezjalny Instytut Akcji Katolickiej.

Dbałowski, Włodzimierz. 1932. „Na marginesie projektu prawa małżeńskiego.” Gazeta Sadowa Warszawska 60, nr 6:71-72.

Dworas-Kulik, Judyta. 2017. „Przyczyny i skutki legalnej bigamii w Polsce w okresie międzywojennym.” W Pogranicza w historii prawa i myśli polityczno-prawnej, red. Dariusz Szpoper, i Przemysław Dąbrowski, 109-29. Gdańsk-Olsztyn: Wydawnictwo GSW.

Dworas-Kulik, Judyta. 2019. Prawne regulacje dotyczqce bigamii $w$ Polsce $w$ latach 19181939. Lublin: Wydawnictwo KUL.

Fiedorczyk, Piotr. 2005. „Wykorzystanie dorobku Komisji Kodyfikacyjnej Drugiej Rzeczypospolitej w pracach nad unifikacją osobowego prawa małżeńskiego w 1945 roku." Zeszyty Prawnicze Towarzystwa Biblioteki Słuchaczów Prawa UJ 13:89-96.

Giduljanov, Pavel. 1927. Kodeks zakonov o brake, sem'e $i$ opeke s postatejnym kommentariem. Leningrad: Rabochij sud.

Godlewski, Jerzy. 1967. „Problem laicyzacji osobowego prawa małżeńskiego w Polsce międzywojennej." Państwo i Prawo 22, z. 11:756-59.

Kushnir, Liudmyla. 2010. „Povsiakdenni realii robitnychykh simej Donbasu u 1920-1930-khrokakh.” Kraieznavstvo 3:178-82.

Lutostański, Karol. 1932a. „O metodach stosowanych w polemice z Projektem Prawa Małżeńskiego Komisji Kodyfikacyjnej.” Gazeta Sadowa Warszawska 60, nr 21:289-92.

Lutostański, Karol. 1932b. „Uwagi z powodu projektu pracy L. Domańskiego «O małżeństwie»." Gazeta Sądowa Warszawska 60, nr 27:525-30, nr 38:541, nr 39:557-62.

Mezglewski, Artur, i Anna Tunia. 2007. Wyznaniowa forma zawarcia małżenstwa cywilnego. Warszawa: Wydawnictwo C.H. Beck.

Mikheieva, Oksana. 2013. „Problemy shliubnykh vidnosyn u konteksti radians'koi simejnoi polityky v Ukraini na pochatku 1920-kh rr. (za materialamy fakhovykh iurydychnykh vydan' ta hazet)." Istorychni $i$ politolohichni doslidzhennia 4:128-33.

Pawluk, Tadeusz. 2002. Prawo kanoniczne wedtug Kodeksu Jana Pawła II. T. 1: Zagadnienia wstępne i normy ogólne. Olsztyn: Warmińskie Wydawnictwo Diecezjalne.

Posvistak, Olesya. 2015. „Vplyv revoliutsijnykh podij 1917 roku na formuvannia teoretychnykh uiavlen' pro shliubno-simejni stosunky.” W Visnyk Natsional'noi akademii Derzhavnoi prykordonnoi sluzhby Ukrainy. Wyd. 1. Seriia: Psykholohiia. http://nbuv. gov.ua/UJRN/Vnadpn_2015_1_9 [dostęp: 29.01.2020].

Prigradov Kudrin, Aleksander. 1922. „Brachnoe pravo i nasledovanie.” W Ezhenedel'nik sovetskoj justicii 12:4-5. https://www.prlib.ru/item/331808 [dostęp: 29.01.2020].

Rulikowski, Wincenty. 1932. „Z dziejów prawa małżeńskiego w Polsce, jak je kler katolicki zwalczał.” Wolnomyśliciel Polski 5, z. 6:161-70. 
Safonchyk, Oksana. 2011. „Deiaki pytannia rozvytku zakonodavstva z pytan’ vynyknennia ta prypynennia shliubno-simejnykh pravovidnosyn." Aktual'ni problemy derzhavy $i$ prava 59:277-84.

Stawecka-Firlej, Agnieszka. 2013. „Małżeńskie prawo osobowe ustawodawstw porozbiorowych obowiązujących w Rzeczypospolitej Polskiej w dwudziestoleciu międzywojennym." Prawo. Studia Historycznoprawne 315, nr 2:75-94.

Szczepaniak, Damian. 2015. „Stanowisko Kościoła katolickiego w Polsce wobec projektu osobowego prawa małżeńskiego Karola Lutostańskiego.” Kortowski Przegląd Prawniczy 2, nr 2:96-104.

Trzeciak, Stanisław. 1932. Talmud, bolszewizm i „Projekt prawa matżeńskiego $w$ Polsce”. Warszawa: Drukarnia Archidiecezjalna.

Woźniczek, Agata. 2011. „Rozbiór krytyczny małżeństwa. Spory o kodyfikację prawa małżeńskiego w II RP.” Więź 5-6:132-41.

Wyszyński, Stefan (przełożył i objaśnił). 1928. Katolicyzm, kapitalizm, socjalizm. List pasterski biskupów austriackich. Lublin: Towarzystwo Wiedzy Chrześcijańskiej.

X. 1932. „Zamachy na małżeństwo katolickie a egzamin przedślubny.” Ateneum Kapłańskie 18 , t. 29 , z. 4:375-77.

Yasynok, Mykola. 2008. „Osoblyvosti sudovoho rozghliadu sprav schodo nadannia nepovnolitnim osobam prava na shliub.” Universytets'ki naukovi zapysky 3:90-93.

\section{Projekt Lutostańskiego a bolszewickie regulacje prawne dotyczące prawa małżeńskiego okresu międzywojennego}

\section{Streszczenie}

Celem artykułu jest analiza projektu prawa małżeńskiego Karola Lutostańskiego z 1929 r. przeprowadzona w ujęciu porównawczym z rozwiązaniami prawnymi obowiązującymi w Rosji Radzieckiej. Zasadność uwzględnienia komparatystyki uzasadnia powoływanie się przez obóz konserwatywny II Rzeczypospolitej na zbieżność treści i założeń projektu Lutostańskiego z bolszewickim ustawodawstwem małżeńskim. Stanowisko takie bezpośrednio stało się przyczyną tego, że projekt nie uzyskał mocy obowiązującej. Wyniki przeprowadzonych badań wskazują na istnienie istotnych rozbieżności tak $\mathrm{w}$ samych założeniach proponowanej regulacji, jak i w zredagowanych w niej przepisach kształtujących model małżeństwa i rodziny, a w konsekwencji państwa. W odróżnieniu od prawa obowiązującego w Rosji, polski projekt w zamierzeniu faktycznie chronił instytucje małżeństwa i rodziny.

Słowa kluczowe: prawo małżeńskie; kodeks Lutostańskiego; ustawodawstwo bolszewickie, rozwód

\section{The Lutostański Draft Law and the Bolshevik Legislations of the Marriage Law in the Interwar Period}

\section{Summary}

The aim of this paper is to analyze of the project marriage law by Karol Lutostanski from 1929, which was carried out in a comparative perspective with legal solutions in 
force in Soviet Russia. The legitimacy of considering comparative studies justifies the reference by the conservative camp of the Second Republic of Poland to the convergence of the content and assumptions of Lutostański's project with Bolshevik marriage legislation. Such a position was a directly reason why the draft did not become effective. The results of the study indicate that there are significant discrepancies, both in the assumption of the proposed regulation and in the edited articles which are shaping the model of marriage and family, and in consequence the state. In contrast to marriage law in Russia, the Polish project in fact aimed to protect the institution of marriage and family.

Key words: marriage law; Lutostan code; Bolshevik legislation; divorce

Information about Author: Judyta Dworas-Kulik, Ph.D. - Department of History of the System and Law, Institute of Legal Sciences, Faculty of Law, Canon Law and Administration, the John Paul II Catholic University of Lublin, Al. Racławickie 14, 20-950 Lublin, Poland; e-mail: dworaskulik@gmail.com; https://orcid.org/0000-00021990-5497

Information about Author: Khrystyna Moriak-Protopopowa, Ph.D. - Department of History of the State, Law and Political Law Teachings, Faculty of Law, Ivan Franko National University of Lviv; 1 Universytetska st., Lviv, 79000, Ukraine; e-mail: khrystyna.moryak-protopopova@lnu.edu.ua; https://orcid.org/0000-0003-1418-240X 